\title{
ADJUSTED OPERATION TIME FOR POOR UNIFORMITY DRIP IRRIGATION NETWORKS
}

\author{
M. K. El-Nemr *
}

\begin{abstract}
Uniformity of water application in drip irrigation system is one of the key criteria that affects crop production and economic operation of the system. Using emitters that introduce a poor emission uniformity (EU), may turn into a must in case of lack of financial resources because of its expected low prices. A field experiment has been taken place under sandy soil conditions on squash crop. Three types of emitters $G, T$, and $M$ were chosen as they had different EU levels acting excellent, good, and poor emission uniformity (EU). Network operation time was calculated basing on emitters' mean flow rate ( $\left.q_{\text {ave }}^{\prime}\right)$, average of lowest quarter flow rates $\left(q_{l q}^{\prime}\right)$, and average of lowest half flow rates $\left(q_{l h}^{\backslash}\right)$. Crop production was significantly affected by emitter type while the base of calculating operation time did not significantly affect crop production. Crop production of emitter $M$ increased by 25 and $35.04 \%$ by changing the operation time basing on $\left(q_{l q}^{\prime}\right)$ and $\left(q_{l h}^{\prime}\right)$ respectively. Energy use efficiency (EUE) for all emitters recorded its greatest values basing on $\left(q_{l q}^{\prime}\right)$. G emitter gave the greatest value of benefits- cost ratio $(B / C)$ compared to the facing treatments of the other two types. Emitter $M$ recorded its greatest $B / C$ ratio with $q_{\text {lh }}$ which was also greater than all obtained $B / C$ ratio of emitter $T$ which had higher EU compared to emitter $M$.
\end{abstract}

\section{INTRODUCTION}

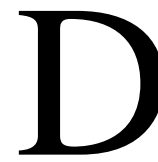
rip irrigation system has the advantage of delivering equal amounts of water to the plants over a wide area (Bressan, 2006). The uniform distribution of water around the field and the root zone affects directly the crop production and water use efficiency. Many studies have been carried out to evaluate the effect of drip irrigation system uniformity on crop yield (Warrick and Gardner, 1983; Letey et al., 1984; Mantovani et al., 1995; Li and Kawano, 1996; and Lopez-Mata et al, 2010;).

\footnotetext{
*Assistant professor, Department of Agricultural Engineering, Faculty of Agriculture, Damietta University. Egypt.
} 
These studies indicated that the more uniform of water application leads to higher crop production. One of the criteria of irrigation system design is the economical suitability of system design to the financial resources of the farm owner (James, 1988).

Limited financial resources of farm owner may lead him to use low price emission devices which may have low uniform of water application. The use of such systems helps to increase cropping intensity and sustainability of agricultural production and consequently increase the income of farmers (Keller 2002; and Ella et al., 2013). Ella et al., 2013 studied the effect of using a device called Adjustable Pressure-Loss Lateral Takeoff Valves (APLTVs) on water distribution uniformity of both types of drip systems under sloping conditions at various operating heads. They used this device with micro tube-type and button-type drip irrigation systems which tends to be relatively non-uniform especially under steep slopes and low operating heads. They considered the cost of this device in design to keep the opportunities of obtaining higher profits. They succeeded to improve the system distribution uniformity that offered the potential to increase crop yield and profitability. El-Nemr, 2013 studied the impact of different levels of emission uniformity of two different emitters on water use efficiency (WUE), energy use efficiency (EUE), and benefit- cost ratio ( $\mathrm{B} / \mathrm{C}$ ratio). He found that despite the higher crop production, WUE and EUE of the high cost emitter, B/C ratios of the lower cost emitter were higher. Sepaskhah and Ghahraman, 2004 studied the combination of irrigation uniformity, system efficiency, and deficit irrigation on the crop production and crop profitability of winter wheat, spring barley, maize, and sorghum in an arid region. They concluded that the higher benefit- cost ratio will reduce the negative effect of low uniformity on crop production. These studies point out that the economic considerations for using low-cost drip system should not be neglected in parallel with trying to improve the system uniformity. On the other hand, low emission uniformity will necessitate greater amounts of water to be applied to meet the plant needs. The operation time of a drip irrigation network is based usually on the average flow rate of 
emitters along laterals. The present study aims to adjust the operation time of a poor uniformity drip irrigation networks by using the values of the mean of lowest half and lowest quarter emitters' flow rates. Resulted operation time variation is expected to give the opportunity for the low flow rate emitters especially at the end of the lateral to apply more water which may help to result more uniform production. Using these values of flow rates to calculate the operation time gives a feature to adjust network operation basing on existing values of flow rates obtained under the network operating conditions. Another feature is that these flow rates are expected to be close to the mean average flow rate which may cause to get out of over irrigation risk especially at the beginning of laterals.

\section{MATERIALS AND METHODS}

\section{Preparation of experimental area:}

The field experiment was carried out in Al-Shahwan Farms, Khatatba village, Menoufia governorate. Egypt (30 $\left.19^{\backslash} \mathrm{N}-30^{\circ} 40^{\backslash} \mathrm{E}\right)$. Squash crop (CA2707) was irrigated using drip irrigation system with 72 hours interval during the successive summer season 2010 in sandy soil (Table-1).

Table- 1- Some physical characteristics of the experimental area soil.

\begin{tabular}{|ccccccc|}
\hline \multirow{2}{*}{ Depth, cm } & \multicolumn{3}{c}{ Particle size distribution, $\%$} & & F.C, & W.P, \\
\cline { 2 - 4 } & Sand & Silt. & Clay. & & $\%$. & $\%$. \\
\hline $0-15$ & 89.69 & 0.47 & 9.84 & Sandy & 9.8 & 4.6 \\
\hline $15-30$ & 90.62 & 0.45 & 9.93 & Sandy & 10.4 & 5.0 \\
\hline $30-45$ & 88.50 & 3.21 & 8.25 & Sandy & 10.9 & 5.1 \\
\hline Mean & 89.69 & 1.38 & 9.34 & & 10.37 & 4.9 \\
\hline
\end{tabular}

The cultivated area was graded to the slope of zero level. The soil chemical analysis showed that soil $\mathrm{pH}$ was 7.85 . Therefore $95.2 \mathrm{~kg} / \mathrm{ha}$ of sulfur was added to reduce alkalinity effect. Electrical conductivity of water was $0.8 \mathrm{dS} / \mathrm{m}$ while SAR (Sodium absorption ratio) was 2.55 , so the irrigation water can be used without any expected problems for salinity or infiltration (FAO, 1980). After germination, the following 
amounts of fertilizers per hectare were injected to the network 3 times weekly for 4 weeks $4.76 \mathrm{~kg}$ of $\mathrm{CO}\left(\mathrm{NH}_{2}\right)_{2}, 4.76 \mathrm{~kg}$ of $\mathrm{NH}_{3}$, and $1.19 \mathrm{~kg}$ of $\mathrm{H}_{3} \mathrm{PO}_{4}$. Also $11.9 \mathrm{~kg}$ of $\mathrm{NH}_{4} \mathrm{NO}_{3}, 14.28 \mathrm{~kg}$ of $\mathrm{K}_{2} \mathrm{SO}_{4}$, and $1.19 \mathrm{~kg}$ of $\mathrm{H}_{3} \mathrm{PO}_{4}$ were added 3 times weekly and stopped fifteen days before the expected date of finishing the harvesting period. A pesticide $2.5 \%$ Mefenoxam, and $40 \%$ Copper with concentration of $1500 \mathrm{~g} / \mathrm{m}^{3}$ of water was used to defend plants against fungus infections. Crop was planted in $5 / 8 / 2010$ with 3 seeds per pore (50 cm spacing) at $15 \mathrm{~cm}$ depth and after germination it was thinned to one plant / pore. Harvesting started at 2/10/2010 till 24/11/2010 with a total 112 days growing season .

\section{Variables and statistical design.}

In order to adjust the network operation time, it was calculated basing on the mean emitters' flow rate ( $q_{\text {ave }}^{\prime}$ ), average of lowest half flow rates $\left(q^{\prime} \mathrm{lh}\right)$, and mean of lowest one-fourth of emitter flow rates $\left(q^{\prime} l_{\mathrm{q}}\right)$. Emitter type variable included three types of emitters which have been mentioned by G, T, and M. Split-plot design was used to study the significance of experimental variables effect on crop production. Irristat 5.0 software was used to perform the required analysis of variance. M-stat 2.0 software was used to perform mean comparison test.

\section{Crop water requirement}

Crop water requirements were calculated referring to (FAO, 1998). CLIMWAT program provides users with the daily reference evapotranspiration $\mathrm{ET}_{\mathrm{o}}$ values $\left(\mathrm{ET}_{\mathrm{o}}, \mathrm{mm} /\right.$ day). Crop factor took the values $0.45,0.7,0.9$ and 0.75 , for the initial, development, mid-season, and late-season growing periods of squash crop (Brouwer and Heibloem, 1986). Total amount of applied water was $3476 \mathrm{~m}^{3}$ /ha for the growing season.

\section{Irrigation network layout.}

The layout of irrigation network is shown in Fig. 1. Laterals $30 \mathrm{~m}$ length, $16 \mathrm{~mm}$ inner diameter, and $1.5 \mathrm{~m}$ spacing between laterals were used with three types of emitters $0.5 \mathrm{~m}$ spacing along lateral. Emitters' types included two on-line emitters referred to the symbols $M$, and $T$ in addition to an in- line type referred to the symbol G (Fig. 2). 


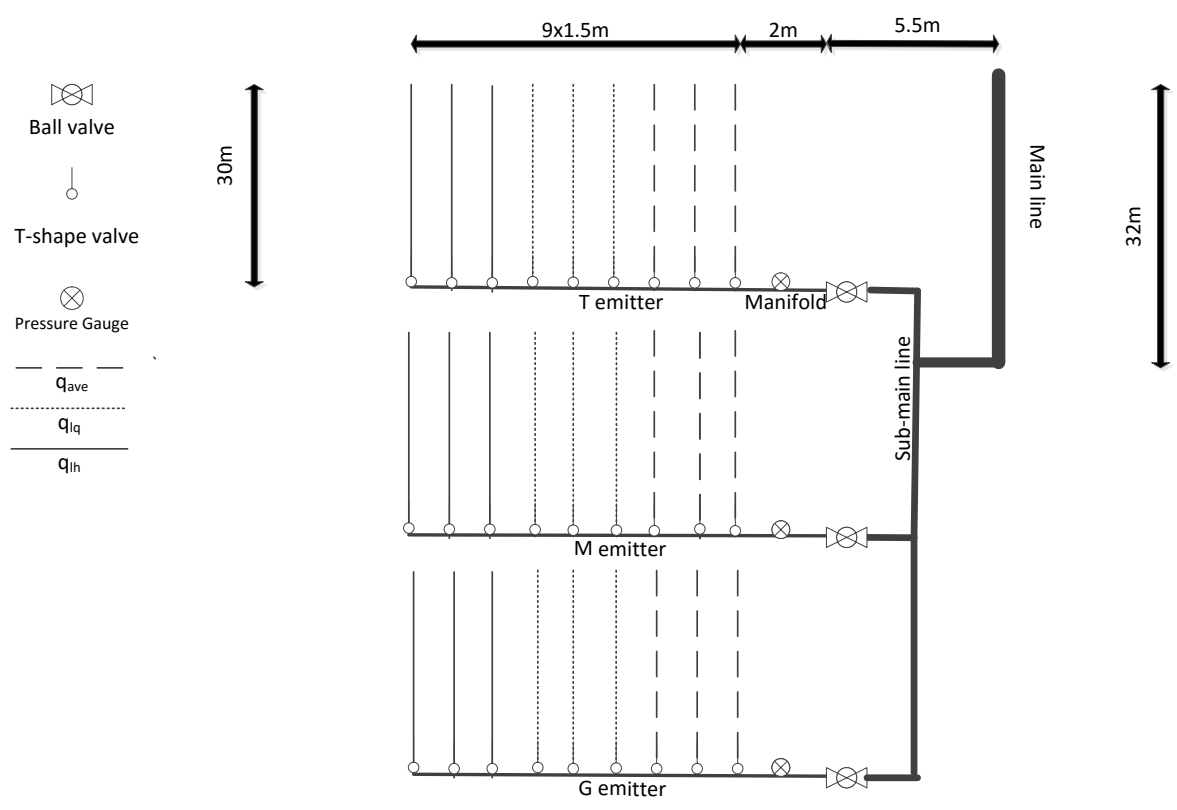

Fig. 1- Schematic diagram for the irrigation network layout.

Emitters' manufacturing specifications are shown in Table.2.

\begin{tabular}{|ccccc|}
\hline \multicolumn{5}{|c|}{ Table. 2: Manufacturing data of emitters. } \\
\hline Emitter symbol & Manufacturer name & Classification & Country of made \\
\hline a) & G & Euro drip & Long- path (in- line) & Egypt \\
\hline b) & T & Arab drip & Turbulent flow (on-line) & Jordan \\
\hline c) & M & Metalic plastic & Simple-orifice (on-line) & Egypt \\
\hline
\end{tabular}

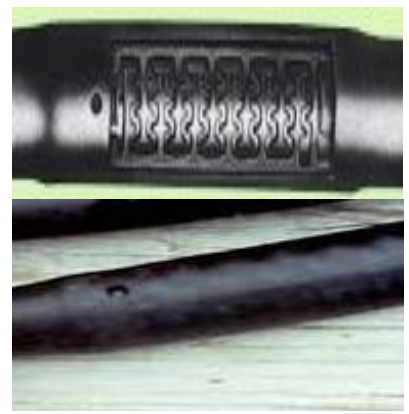

a

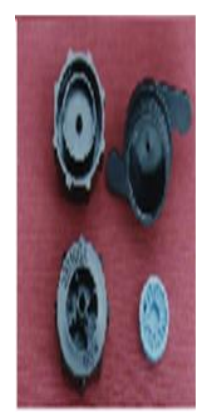

b

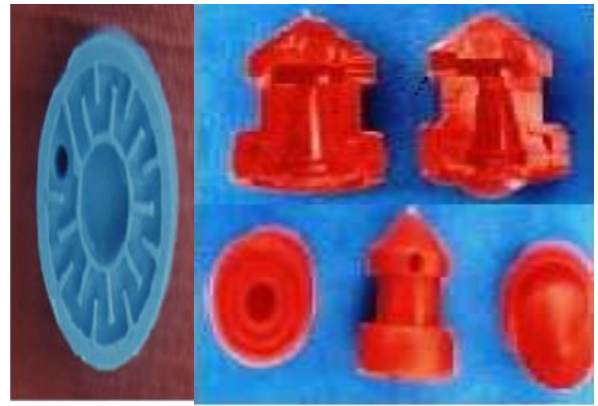

C

Fig. 2: Emitters' design and internal components a)G b)T c)M

Inner diameters of main line, sub-main, and manifolds were 12.7, 7.62, and $5.08 \mathrm{~cm}$ respectively . 


\section{Suitable operating pressure and uniformity parameters.}

The emitter flow rate - pressure relationship $\left(\mathrm{q}-\mathrm{H}_{\mathrm{e}}\right)$ was described with the following formula (Karmeli and Keller, 1975):-

$$
q=k H_{e}{ }^{x}
$$

where $\mathrm{x}$ is the and emitter exponent, $\mathrm{q}=$ emitter flow rate $\mathrm{l} / \mathrm{h}, \mathrm{k}=$ emitter discharge coefficient, and $\mathrm{H}_{\mathrm{e}}$ is the emitter operating head, m. Operating pressure for each emitter type was chosen individually based on primary field experiment to detect the greatest emission uniformity (EU) can the drip irrigation system reach at the selected operating pressures. Laterals were operated at 4 different operation heads $6,8,10$, and $12 \mathrm{~m}$ as an accepted range of operation heads for drip irrigation networks. Lateral length was divided into four imaginary quarters. Five emitters from each quarter were chosen randomly to form 20 emitters' flow rates samples. Discharged water was collected in graded bottles which were put all at once for 2 minutes under the emitters to obtain emitter flow rate. The previous steps were replicated three times on one lateral for each emitter type on the same selected lateral to fix the measuring conditions. Wu et al, 2006 and Barragan et al., 2006 described emission uniformity as follows:-

$$
E U=\frac{q_{l q}^{\prime}}{q_{\text {ave }}}=1-\sqrt{\left[1-\frac{q_{\min }}{q^{\prime}}\right]^{2}+\left[\frac{1.27 C V}{\sqrt{N}}\right]^{2}} \ldots . .2
$$

Where: $q_{\text {ave }}=$ Average of emitters' flow rate, $1 / \mathrm{h}, q^{`}{ }_{l q}=$ mean of lowest one-fourth of emitter flow rates, $1 / \mathrm{h} . C V=$ emitter coefficient manufacture of variation, $\%$ and $\mathrm{N}=$ number of emitters per plant which was 1 under the experiment conditions. $\mathrm{CV}$ was calculated referring to (Keller and Karmeli, 1974).

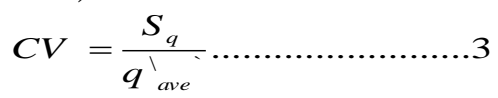

Where: $S_{q}=$ standard deviation of emitters' flow rate. Flow rate variation $\mathrm{q}_{\mathrm{var}}$ was calculated using the following equation (Wu and Gitlin, 1975).

$$
q_{\mathrm{var}}=\frac{q_{\max }-q_{\min }}{q_{\max }} \times 100 \ldots \ldots \ldots . . .4
$$

Where: $\mathrm{q}_{\max }=$ maximum emitter flow rate $1 / \mathrm{h}$, and $\mathrm{q}_{\min }=$ minimum emitter flow rate, $1 / h$. Table. 3 lists the values of $q_{\text {ave, }}^{\prime} q_{\text {lq, and }}^{\prime} q_{\text {lh }}^{\prime}$ of G, T and M emitters under the recommended operating pressure head. 
Table. 3: Values of flow rates $(\mathrm{l} / \mathrm{h})$ used to calculate network operation time.

\begin{tabular}{|ccccc|}
\hline Emitter & Operation head, $\mathrm{m}$ & $\mathrm{q}_{\text {ave }}^{\prime}$ & $\mathrm{q}_{\mathrm{lq}}$ & $\mathrm{q}_{\mathrm{lh}}$ \\
\hline $\mathrm{G}$ & 10 & 3.2 & 2.76 & 2.88 \\
\hline $\mathrm{T}$ & 12 & 4.06 & 3.62 & 3.76 \\
\hline $\mathrm{M}$ & 12 & 6.74 & 3.41 & 3.68 \\
\hline
\end{tabular}

\section{Water application efficiency $\left(E_{a}\right)$.}

Water application efficiency $\left(E_{a}\right)$ represents the efficiency of water application in the field. Wu and Giltin (1973) used the following formula to express the application efficiency of a drip irrigation system:

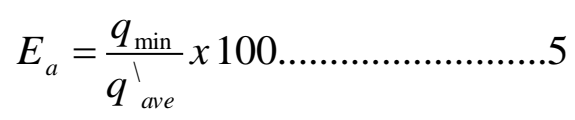

\section{Crop production}

The total weight of squash fruit produced in every replicate was weighed on $10 \mathrm{~g}$ accuracy scale. The whole fruits under each replicate were picked when squash fruit reached the accepted market size $(10-15 \mathrm{~cm}$ long). The average of the three replicates was multiplied to 222.2 to get the crop yield per hectare for each treatment.

\section{Energy use efficiency (EUE):}

Power requirement, energy consumption, and energy use efficiency (EUE) was calculated referring to the methodology of (El-Nemr, 2013). Hazen-Williams formula (Hazen and Williams, 1920) was used to calculate the major friction loss for which included main, sub-main, manifold, and laterals losses. The minor friction loss in connectors and valves was assumed $10 \%$ of the total friction loss (El-Gindy et al., 2001). Pumping efficiency assumed as 0.7 . Power requirement of each treatment was calculated per hectare assuming the whole unit of area is working neglecting any management effect.

\section{Crop profitability}

The total annual cost per hectare for the growing season was calculated referring to (Buchanan and cross, 2002) based on the Egyptian market information of year 2010. The total cost is equal to the summation of total annual fixed and variable costs. Fixed costs included depreciation of network components, interest, and taxes and insurance costs. The depreciation costs of the different irrigation network components were calculated as follows:- 


$$
\text { Annual depreciation }=\frac{\text { Capital price- } \text { price at the end of life duration }}{\text { Life duration }}
$$

The variable costs included fuel, oil and lubricants, labor, repair and maintenance, and additive costs including pesticides, fertilizers, seeds, and transportation. The end life price of an object was assumed $10 \%$ of the capital price. Life duration of the pump and network components was assumed 10 years. The interest value was $10 \%$ while taxes and insurance were $2 \%$ of the main price of an object. The fuel consumption of diesel engine, 1/h was calculated referring to (Culpin, 1976 and Kepner et al, 1978) as shown in Equation. 7. Price of diesel fuel was 0.15 US\$/ 1.

$$
F_{c}=0.12 . \mathrm{BP}_{E} \ldots \ldots \ldots \ldots .7
$$

Where: $F_{c}=$ fuel consumption, $1 / \mathrm{h}$, and $\mathrm{BP}_{\mathrm{E}}=$ Engine break power, hp. Oil and lubricants were assumes $15 \%$ of total fuel costs (El-Dnasoury, 2001). Labor fees were 1.82 US\$/day/person for 8 hours working day. Repairs and maintenance costs were assumed to be equal to the depreciation cost. The summation of seasonal additive costs was $256.48 \mathrm{US} \$$. Cost of G type laterals was $9.56 \mathrm{US} \$ / 100 \mathrm{~m}$ while it was $15.94 \mathrm{US} \$ / 100 \mathrm{~m}$ of $\mathrm{T}$ emitter and $8.74 \mathrm{US} \$ / 100 \mathrm{~m}$ of $\mathrm{M}$ emitter lateral. Benefits obtained by the farmer for selling squash crop was $0.15 \mathrm{US} \$ / \mathrm{kg}$. The benefits- cost ratio $(\mathrm{B} / \mathrm{C})$ was used to describe the final crop profitability.

\section{RESULTS AND DISCUSSIONS}

\section{System uniformity and suitable operating pressure head.}

Data listed in Table. 4 points out that the EU values of Emitters G, T, and $\mathrm{M}$ under the selected experiment operating pressure are evaluated Excellent, Good, and poor (ASAE,1994). According to the resulted EU values which are listed in Table. 4, G type was recommended to operate at $10 \mathrm{~m}$ while the two other types were operated at $12 \mathrm{~m}$.

Table- 4: Mean values of of EU, \% for $G$ and $T$ emitters under different operating pressure heads.

\begin{tabular}{|ccccc|}
\hline \multirow{2}{*}{ Emitter type } & \multicolumn{5}{c|}{ Operating head, m } \\
\cline { 2 - 5 } & 6 & 8 & 10 & 12 \\
\hline $\mathrm{G}$ & 83.80 & 88.81 & 97.10 & 91.00 \\
\hline $\mathrm{T}$ & 74.65 & 88.51 & 88.89 & 89.35 \\
\hline $\mathrm{M}$ & 42.65 & 36.51 & 50.7 & 51.64 \\
\hline
\end{tabular}


Flow rate distribution behavior of different emitters along lateral is shown in Figure. 3, which points out that emitter $M$ has higher flow rate variation compared to $\mathrm{T}$ and $\mathrm{G}$ emitters. $\mathrm{q}_{\mathrm{var}}$ for $\mathrm{M}$ emitter was $79.29 \%$ while it was 21 and $25 \%$ for $\mathrm{T}$ and $\mathrm{G}$ emitters respectively. This may explain the poor uniformity of $\mathrm{M}$ emitter drip system network.

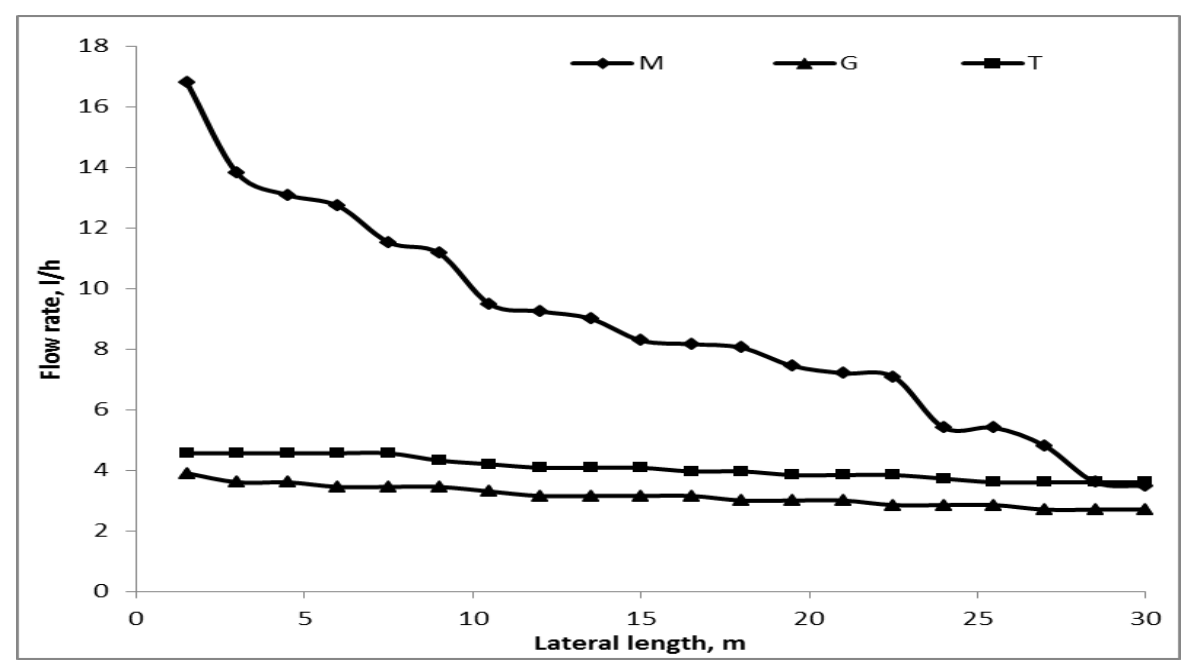

Fig.3: Flow rate distribution along lateral length for the different types of emitters.

EU and $\mathrm{q}_{\mathrm{var}}$ values reflect the emitter exponent values of emitters $\mathrm{T}$ and $\mathrm{G}$ which are shown in Table. 5 that they are considered pressure compensating emitters (James, 1988). Despite the poor uniformity of emitter $M$ but its emitter exponent (x) value refers to a pressure compensating emitter which is not in agreement with its EU and application distribution behavior. Von Bernuth and Solomon, 1986 pointed out that the regression fit of flow rate- pressure relationship would be obtained when emitter operates in the transition regime somewhere in its operating pressure range. Poor performance and high flow rate variation of emitter $M$ caused a non- descriptive value of $\mathrm{x}$.

Table-5: Average value of emitters' flow rates, $\mathrm{l} / \mathrm{h}$ and $\mathrm{q}-\mathrm{H}_{\mathrm{e}}$ relationship.

\begin{tabular}{|cccccc|}
\hline \multirow{2}{*}{ Emitter type } & \multicolumn{4}{c}{ Operating pressure head, m } & Flow rate-pressure \\
\cline { 2 - 5 } & 6 & 8 & 10 & 12 & relationship \\
\hline a) $\mathrm{G}$ & 2.26 & 3.05 & 3.20 & 3.79 & $\mathrm{q}=1.02 \mathrm{H}_{\mathrm{e}}{ }^{0.25}$ \\
\hline b) $\mathrm{T}$ & 2.74 & 3.50 & 4.00 & 4.06 & $\mathrm{q}=0.83 \mathrm{H}_{\mathrm{e}}{ }^{0.34}$ \\
\hline c) $\mathrm{M}$ & 6.53 & 6.62 & 6.74 & 8.78 & $\mathrm{q}=1.46 \mathrm{H}_{\mathrm{e}}{ }^{0.39}$ \\
\hline
\end{tabular}




\section{Water application efficiency (WAE).}

$E_{a}$ values were $39.63,96.97 \%$, and $88.67 \%$. $E_{a}$ values for $G$ and $T$ emitters were within the expected range shown by (Howell, 2003) for surface drip irrigation system while the $E_{a}$ of $M$ emitter was out of this range. Proportional relationship between $\mathrm{EU}$ and $\mathrm{E}_{\mathrm{a}}$ was noticed as explained by (Mirjat et al. 2010) that the higher uniformity will result higher $\mathrm{E}_{\mathrm{a}}$.

\section{Crop production.}

Table. 6 shows analysis of variance of the experimental variables effect on crop production. Emitter type has a significant effect on crop production as an impact for the variation in emission uniformity. Value of flow rate that reflects the effect of network operation time did not make a significant effect on the crop production. This result may be due to the higher emission uniformity of both emitters $\mathrm{G}$ and $\mathrm{T}$ which reduced the effect of changing the average flow rate value.

Table. 6: Analysis of variance of the effect of emitter type (E) and base flow rate

value of calculating operation time (A) on crop production

\begin{tabular}{|c|c|c|c|c|}
\hline & DF & Sum of squares & Mean squares & F-Ratio \\
\hline E & 2 & 66.16 & 33.08 & $4.76^{*}$ \\
A & 2 & 17.74 & 8.87 & 1.28 \\
ExA & 4 & 26.22 & 6.56 & 0.94 \\
Residual & 18 & 125.147 & 6.95 & 0.98 \\
\hline Total & 26 & 235.27 & 9.05 & \\
\hline
\end{tabular}

Note: *significant at $5 \%$ level

Data listed in Table. 7 show the squash production values at different treatments. There was no significant difference between the crop production resulted with $\mathrm{G}$ and $\mathrm{T}$ emitters while there was a significant difference between $\mathrm{q}_{\text {ave }}^{\prime}$ treatment and the two other treatments of $\mathrm{M}$ emitter. This clarifies that $\mathrm{M}$ emitter which has the lowest EU value, the variation in the value of emitter's average flow rate resulted in a significant variation in crop production between its treatments. The greatest crop production obtained from emitters $\mathrm{G}$ and $\mathrm{T}$ was with the $\mathrm{q}$ lq treatment with 17.21 and $16.01 \mathrm{Mg} / \mathrm{ha}$ respectively. Emitter $\mathrm{M}$ has its greatest crop production at $\mathrm{q}_{\mathrm{lh}}^{\prime}$ treatment. Changing the operation time 
led to increase crop production for $\mathrm{M}$ emitter by 25.00 , and $35.04 \%$ of $\mathbf{q}$ lq and $q$ 'h production respectively. $G$ emitter recorded the greatest crop production compared to the facing treatments for the other two emitters. This result may be due to the higher EU it has if compared to the other two types as mentioned by (Lopez-Mata et al, 2010; Bhatnagar and Srivastava, 2003)

Table.7: Mean comparison test of crop production values (Mg/ha).

\begin{tabular}{|cccc|}
\hline & $\mathbf{T}$ & $\mathbf{G}$ & $\mathbf{M}$ \\
\hline $\mathbf{q}$ & $15.66 \mathrm{a}$ & $16.92 \mathrm{a}$ & $10.14 \mathrm{~b}$ \\
\hline $\mathbf{q}^{\prime} \mathbf{l q}$ & $16.01 \mathrm{a}$ & $17.21 \mathrm{a}$ & $13.52 \mathrm{ab}$ \\
\hline $\mathbf{q}^{\prime} \mathbf{l}$ & $15.42 \mathrm{a}$ & $16.57 \mathrm{a}$ & $15.61 \mathrm{a}$ \\
\hline
\end{tabular}

Note: Values followed by the same single letter is not significantly different at $5 \%$ level. L.S.D=4.467

\section{Energy consumption and use efficiency (EUE).}

Table. 8 shows the irrigation time during growing season per hectare. $G$ emitter showed higher operation time if compared to $\mathrm{T}$ and $\mathrm{M}$ emitters. This may be due to the less flow rate it has.

Table. 8: Network operation time $\mathrm{h} / \mathrm{season}$ for different treatments.

\begin{tabular}{|cccc|}
\hline & T & G & M \\
\hline qave & 64.21 & 81.46 & 38.56 \\
\hline $\mathbf{q}_{\text {lq }}$ & 72.02 & 94.46 & 76.46 \\
\hline q $_{\text {lh }}$ & 69.34 & 90.52 & 70.84 \\
\hline
\end{tabular}

Power requirement for $G$ emitter was the lowest while power requirement of $\mathrm{M}$ emitter tends to be higher than the other two types except at $\mathrm{q}_{\mathrm{lq}}^{\prime}$ treatment which was lower than the requirement of $\mathrm{T}$ emitter (Table.9). Using $\mathrm{M}$ emitter basing on $\mathrm{q}_{\text {ave }}^{\prime}$ flow rate will increase the network power needs by 65.05 , and $53.5 \%$ of the maximum power requirement of $\mathrm{M}$ emitter compared to $\mathrm{G}$ and $\mathrm{T}$ emitter respectively. Basing on $\mathrm{q}^{\prime} \mathrm{lq}$ and $\mathrm{q}_{\mathrm{lh}}^{\mathrm{h}}$ will decrease the power requirement for $\mathrm{M}$ emitter network by 60.1 , and $53.53 \%$ of qave required power.

Table.9: Power requirement $(\mathrm{kW} / \mathrm{ha})$ for the network under the experimental conditions.

\begin{tabular}{|llll|}
\hline & T & G & M \\
\hline qave & 27.83 & 20.92 & 59.85 \\
\hline q'lq $_{\text {lq }}$ & 24.38 & 17.77 & 23.88 \\
\hline q'th $^{\text {th }}$ & 25.46 & 18.63 & 27.81 \\
\hline
\end{tabular}


(Yildrim, 2007) mentioned that the emitters' hydraulic characteristics and total energy loss affects the water application uniformity. The poor uniformity of emitter $\mathrm{M}$, led to the higher requirements of power if compared to $\mathrm{T}$ and $\mathrm{G}$ emitter with $\mathrm{q}_{\text {ave. Energy consumption values }}^{\prime}$ shown in Table. 10 clarify that the energy consumption of emitter $\mathrm{M}$ which has the least uniformity can be reduced by 42.02 , and $14.64 \%$ of the maximum energy consumption of the same emitter by modifying the operation time based on $\mathrm{q}_{\mathrm{lq}}^{\mathrm{l}}$ and $\mathrm{q}_{\mathrm{lh}}$ respectively. EUE values shown in Table. 10, indicate that the maximum EUE was obtained under $\mathrm{G}$ emitter with $\mathrm{q}_{\mathrm{lq}}^{\prime}$ treatment. The lowest EUE was under $\mathrm{M}$ emitter with $\mathrm{q}_{\text {ave. }}^{\prime} \mathrm{G}$ emitter treatments gave the greatest EUE compared to the other types. The greatest EUE for $\mathrm{M}$ emitter was obtained with $\mathrm{q}_{\mathrm{lq}}$. An increase of 56.53 , and $21.58 \%$ of the greatest EUE obtained at $\mathrm{M}$ emitter will occur as a result of using $\mathrm{q}_{\mathrm{lq}}^{\mathrm{lq}}$ instead of $\mathrm{q}_{\text {ave }}^{\prime}$ and $\mathrm{q}_{\mathrm{lh}}^{\prime}$ respectively. The three emitters obtained their greatest EUE with $q_{\text {lq. }}^{\prime}$. The difference between the greatest and least EUE of all emitters was 4.28, 4.09, and $56.53 \%$ of their greatest EUE for T, G, and M emitters respectively.

Table. 10: Energy consumption $(\mathrm{kW} . \mathrm{h})$ and EUE values $(\mathrm{kg} / \mathrm{kW} . \mathrm{h})$ under the experimental conditions.

\begin{tabular}{|ccccccc|}
\hline & \multicolumn{3}{c}{ Energy consumption, kW.h } & \multicolumn{3}{c|}{ EUE, kg/ kW.h } \\
\cline { 2 - 7 } & $\mathbf{T}$ & $\mathbf{G}$ & $\mathbf{M}$ & $\mathbf{T}$ & $\mathbf{G}$ & $\mathbf{M}$ \\
\hline qave & 1786.96 & 1704.14 & 2307.82 & 8.76 & 9.93 & 4.39 \\
\hline $\mathbf{q}_{\text {lq }}$ & 1755.85 & 1678.55 & 1338.05 & 9.12 & 10.25 & 10.10 \\
\hline $\mathbf{q}_{\text {lh }}$ & 1765.40 & 1686.39 & 1970.06 & 8.73 & 9.83 & 7.92 \\
\hline
\end{tabular}

\section{Benefits- cost ratio.}

The $\mathrm{B} / \mathrm{C}$ ratios of all treatments are shown in Table. 11. Greatest $\mathrm{B} / \mathrm{C}$ ratio obtained for $\mathrm{M}$ emitter was at $\mathrm{q}_{\mathrm{lh}}^{\prime}$ while it was at $\mathrm{q}_{\mathrm{lq}}^{\prime}$ with $\mathrm{G}$ and $\mathrm{T}$ emitters. $\mathrm{M}$ emitter recorded a $\mathrm{B} / \mathrm{C}$ ratio of 0.68 based on $\mathrm{q}_{\text {ave }}^{\prime}$ flow rate. Because of the high flow rate, the pumping cost increased the total fixed cost for this treatment which turned into a non-economic one. It was noticed that the smaller required pump leads to decrease the total cost and turn the system to be operated in economic way (Alabas, 2013). This non-economic situation may change with a higher beneficial crop, so it can't be a general role that poor emission uniformity may result a noneconomic treatment. It was not expected that $\mathrm{M}$ emitter can result the 
greatest $\mathrm{B} / \mathrm{C}$ ratio compared to the two other types because of the low uniformity which affected the total production. The change in operation time and power requirement resulted from basing on $\mathrm{q}_{\mathrm{lq}}^{\prime}$ and $\mathrm{q}_{\mathrm{lh}}^{\prime}$ of $\mathrm{M}$ emitter, led to increase $\mathrm{B} / \mathrm{C}$ ratio by $53.74 \%$, and $59.76 \%$ of $\mathrm{B} / \mathrm{C}$ ratio for $\mathrm{q}_{\mathrm{lq}}^{\prime}$ and $\mathrm{q}_{\mathrm{lh}}^{\prime}$, respectively. The maximum obtained $\mathrm{B} / \mathrm{C}$ ratio with $\mathrm{M}$ emitter was higher than all $\mathrm{B} / \mathrm{C}$ ratio obtained under $\mathrm{T}$ emitter. $\mathrm{G}$ emitter recorded the greatest $\mathrm{B} / \mathrm{C}$ ratio if compared to the facing treatments of the other two emitters. This may be due to the higher production of $\mathrm{G}$ emitter resulted from the excellent EU and the moderate annual operating costs.

Table. 11: Seasonal B/C ratios of $M, G$, and T emitters' networks.

\begin{tabular}{|c|c|c|c|c|c|c|c|c|c|}
\hline & \multicolumn{3}{|c|}{$\mathbf{T}$} & \multicolumn{3}{|c|}{ G } & \multicolumn{3}{|c|}{$\mathbf{M}$} \\
\hline & $\mathbf{q}_{\text {ave }}$ & $q^{\prime} \mathrm{lq}$ & $q^{\prime} / h$ & qave & $q^{\prime} \mathrm{lq}$ & $q^{\prime}$ lh & $\mathbf{q}_{\text {ave }}$ & $q^{\prime} \mathrm{lq}$ & $q^{\prime} l_{h}$ \\
\hline Depreciation & 379.61 & 379.61 & 379.61 & 317.66 & 281.66 & 281.66 & 646.09 & 277.09 & 343.60 \\
\hline Interest & 231.98 & 231.98 & 231.98 & 194.12 & 172.12 & 172.12 & 394.83 & 169.33 & 209.98 \\
\hline $\begin{array}{l}\text { Taxes and } \\
\text { insurance }\end{array}$ & 84.36 & 84.36 & 84.36 & 70.59 & 62.59 & 62.59 & 143.57 & 61.57 & 76.35 \\
\hline $\begin{array}{l}\text { Total fixed } \\
\text { costs }\end{array}$ & 695.95 & 695.95 & 695.95 & 582.37 & 516.37 & 516.37 & 1184.49 & 507.99 & 629.93 \\
\hline Fuel & 43.12 & 42.37 & 42.60 & 41.12 & 40.50 & 40.69 & 55.85 & 44.06 & 47.53 \\
\hline $\begin{array}{c}\text { Oil and } \\
\text { lubricants }\end{array}$ & 6.47 & 6.35 & 6.39 & 6.17 & 6.08 & 6.10 & 8.38 & 6.61 & 7.13 \\
\hline Labor & 97.45 & 97.45 & 97.45 & 97.45 & 97.45 & 97.45 & 97.45 & 97.45 & 97.45 \\
\hline \begin{tabular}{|l|} 
Repairs and \\
maintenance
\end{tabular} & 379.61 & 379.61 & 379.61 & 317.66 & 281.66 & 281.66 & 646.09 & 343.60 & 343.60 \\
\hline Additives & 256.48 & 256.48 & 256.48 & 256.48 & 256.48 & 256.48 & 256.48 & 256.48 & 256.48 \\
\hline $\begin{array}{c}\text { Total } \\
\text { variable } \\
\text { costs } \\
\end{array}$ & 783.12 & 782.26 & 782.52 & 718.87 & 682.16 & 682.38 & 1064.24 & 748.19 & 752.19 \\
\hline \begin{tabular}{|c|} 
Total annual \\
costs
\end{tabular} & 147 & 478. & 478 & 301 & 198 & 198 & 24 & 378 & 1382 \\
\hline Benefits & 2349.00 & 2401.50 & 2313.00 & 2538.00 & 2581.50 & 2485.50 & 1521.00 & 2028.00 & 2341.50 \\
\hline $\mathrm{B} / \mathrm{C}$ ratio & 1.59 & 1.62 & 1.56 & 1.95 & 2.15 & 2.07 & 0.68 & 1.47 & 1.69 \\
\hline
\end{tabular}

\section{CONCLUSION}

The study results can be concluded as follows under this field experiment conditions:

1- Changing drip irrigation network operation time basing on different emitters' average flow rate values does not have a significant effect on crop production for excellent and good EU. It 
makes a significant difference on crop production for poor uniformity emitters.

2- Basing on $q_{\text {lq }}^{\prime}$ for calculating operation time will increase the EUE of all emitters.

3- In case of poor energy resources supplies or high cost energy resources, it is recommended to calculate the operation time of poor uniformity drip irrigation networks basing on $\mathrm{q}_{\mathrm{lq}}$.

4- Economic consideration is the most important criteria for using poor uniformity emitters. It is recommended to calculate network operation time basing on $\mathrm{q}_{\mathrm{lh}}^{\prime}$ to obtain higher $\mathrm{B} / \mathrm{C}$ ratio.

5- Adjusting operation time basing on $\mathrm{q}_{\mathrm{lh}}^{\mathrm{h}}, \mathrm{B} / \mathrm{C}$ ratio of poor uniformity networks can exceed the $\mathrm{B} / \mathrm{C}$ ratio obtained from a high cost emitter with good EU but can't exceed the ratios obtained from an excellent EU networks with moderate cost.

\section{REFERENCES}

Alabas, M. A. (2013). Evaluation the hydraulic performance of drip Irrigation system with multi cases. Global Journal of Researches in Engineering General Engineering Volume 13(2): 12-18.

ASAE. (1994). ASAE Engineering practice. American Society of Agricultural Engineers, EP405: 724-727.

Barragan, J.; V. Bralts; and I.P. Wu (2006). Assessment of emission uniformity for micro-irrigation design. Biosystems Engineering, 93(1): 89-97.

Bhatnagar, P. R. and R.C. Srivastava. (2003). Gravity-fed drip irrigation system for hilly terraces of the northwest Himalayas. Irr. Sci., 21:151- 157 .

Bressan, T (2006). Drip irrigation handbook, the Catalog for Getting Started. The Urban Farmer Store, Inc. p2.

Brouwer, C.; and M. Heibloem (1986). FAO irrigation water management training manual no. 3, part II. Determination of irrigation water needs. 
Buchanan, R.J.; and T.L. Cross (2002). Irrigation Cost Analysis Hand Book. Agricultural Extension Service. The University of Tenessee. PB1721.

Culpin, C. (1976). Farm Machinery, 9th edition, Crosby Lockwood staples, London.

El-Dnasoury, M. M. (2001). Farm machinery, types and performance evaluation methods (in Arabic). Academic library, Cairo, Egypt.

El-Gindy, A.M.; A.A. Abdelaziz; and A.A. Soliman (2001). Irrigation and Drainage Networks Design, (in Arabic) Ain Shams University, Egypt.

Ella, V.B.; J. Keller; M. Reyes; and B. Yoder. (2013). A low-cost pressure regulator for improving the water distribution uniformity of a microtube-type drip irrigation system. Applied Engineering in Agriculture, 29(3):343-349

El-Nemr, M.K. (2013). Role of emission uniformity in the sustainable management of drip irrigation system. World Research Journal of Agricultural \& Biosystems Engineering, Vol 2(1):17-23.

FAO. (1980). Irrigation and drainage paper 36.Localized irrigation. Rome.

FAO. (1993). CLIMWAT for CROPWAT. FAO irrigation and drainage paper 49(1993).

FAO. (1998). Crop evapotranspiration - Guidelines for computing crop water requirements. FAO Irrigation and drainage paper 56.

Hazen, A.; and G.S. Williams (1920). Hydraulic Tables, 3rd ed., John Wiley and Sons, New York.

Howell, T.A. (2003). Irrigation Efficiency, in Encyclopedia of Water Science. Marcel Dekker, Inc. New York, New York. 1076 pp.

James, L.G. (1988). Principles of farm irrigation system design. John willey \& sons, inc. 
Karmeli, D.; and J. Keller (1975).Trickle irrigation design .Rain Bird sprinkler manufacturing crop. Glendora, California, 133.

Keller, J.; and D. Karmeli (1974). Trickle irrigation design parameters. Transaction of the ASAE, 17 (4), 678-684.

Keller, J. (2002). Evolution of drip/microirrigation: traditional and nontraditional uses. Paper presented as keynote address at the International Meeting on Advances in Drip/Micro Irrigation, December 2 to 5, 2002, Puerto de la Cruz, Tenerife, Spain.

Kepner, R.A.; R. Bainer; and E.L. Barger (1978). Principles of Farm Machinery. 3rd Ed, AVI Publishing Company Inc., Westport, Connecticut, USA.

Letey, J.; H.J. Vaux; and E. Feinerman (1984). Optimum crop water application as affected by uniformity of water infiltration. Agron. J. 76: 435-441.

Li, J.; and H.Kawano (1996). The areal distribution of soil moisture under sprinkler irrigation. Agricultural Water Management. 32: 2936.

López-Mata, E.; J.M. Tarjuelo; J.A. de Juan; R. Ballesteros; and A. Domínguez (2010). Effect of irrigation uniformity on the profitability of crops. Agricultural Water Management, 98 (2010): 190-198.

Mantovani, E.C.; F.J. Villalobos; F. Orgaz; E. Fereres (1995). Modeling the effects of sprinkler irrigation uniformity on crop yield. Agric. Water Manage. 27: 243-257.

Mirjat, M. S.; M. U. Mirjat; and F. A. Chandio (2010). Water distribution pattern, discharge uniformity and application Efficiency of locally made emitters used in a trickle subunit. Pak. J. Agri., Agril. Engg., Vet. Sci., 2010, 26 (1): 1-15.

Sepaskhah, A.R.; and B. Ghahraman (2004). The effects of irrigation efficiency and uniformity coefficient on relative yield and profit for deficit irrigation. Biosystems Engineering 87 (4), 495-507. 
Von Bernuth, R.D.; and K.H. Solomon, 1986. Design principles in Nakayama, F.S. and D.A. Bucks (1986). ELSEVIER Science Publishers.p31.

Warrick, A.W.; W.R. Gardner (1983). Crop yield as affected by spatial variations of soil and irrigation. Water Resour. Res. 19:181-186.

Wu, I. P., and H. M. Gitlin. (1973). Hydraulics and uniformity of drip irrigation. Journal of Irrigation and Drainage Division, ASCE, 99(2): $157-167$.

Wu, I.P. and H.M. Gitlin (1975). Energy gradient line for drip irrigation laterals. J.Irrig. and Drain. Div., Amer.Soc.Civil Eng.101(IR4):321-326.

Wu, I. P.; J. Barragan, and V. Bralts (2006). Field performance and evaluation. In F. R. Lamm, J.E. Ayars; and F. S. Nakayama (Eds.), Micro-irrigation for crop production, Amsterdam. Elsevier, 357387.

Y1ldırım, G. (2007). An assessment of hydraulic design of trickle laterals considering effect of minor losses. Irrig Drain (ICID Journal) 56(4):399-421

\section{الملخص العربيى}

ضبط زمن تثنغيل شبكات الرى بالتنقيط ذات الانتظامية الفقيرة

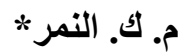

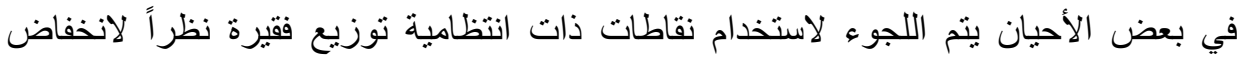

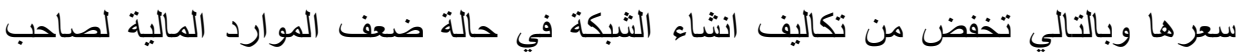

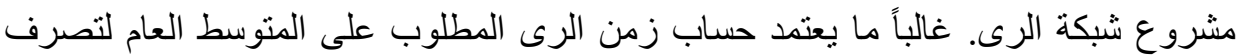

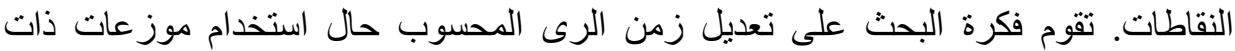

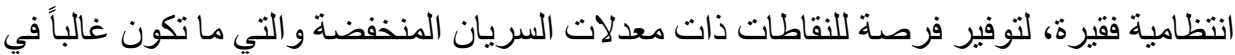

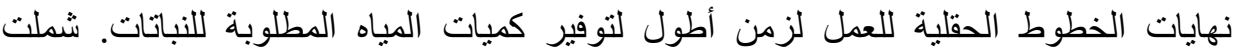

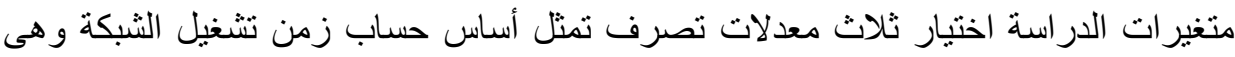

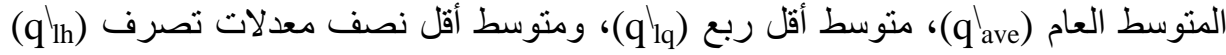
للنقاطات للعمل مع ثلاثة أنواع من النقاطات

*مدرس بقسم الهندسة الزراعيةـ كلية الزراعةـ جامعة دمياط 


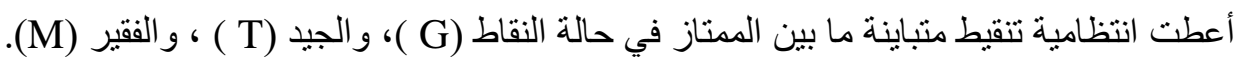

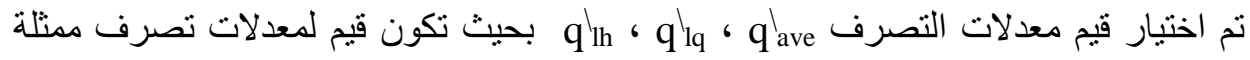

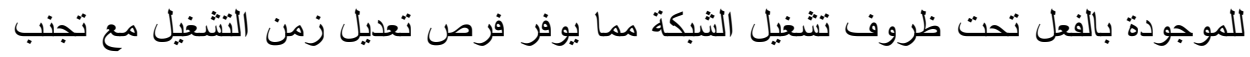

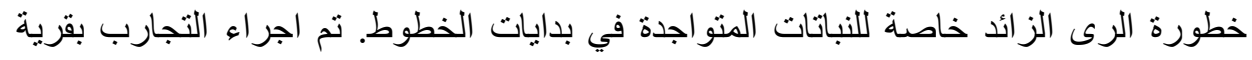

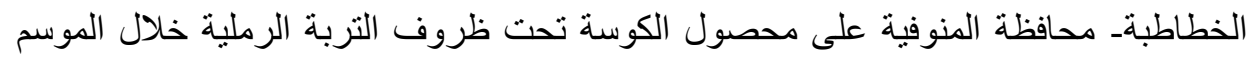

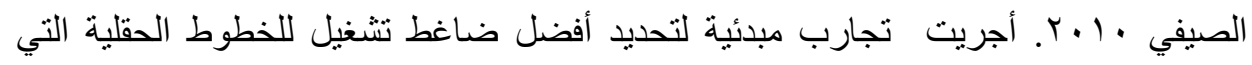

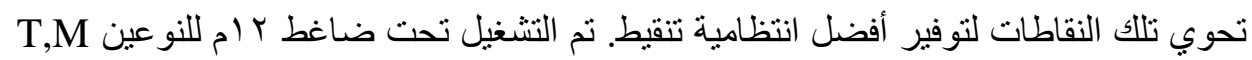

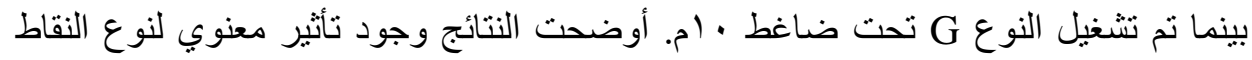

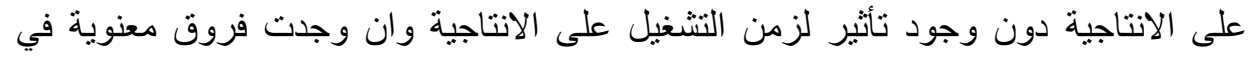

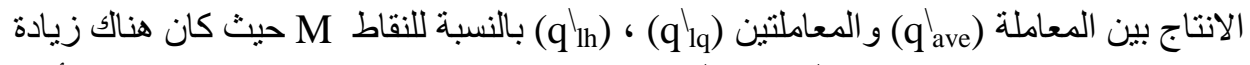

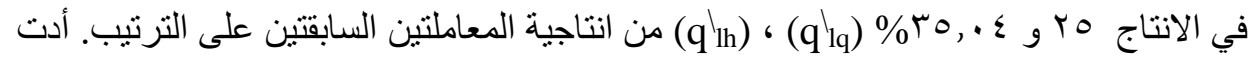

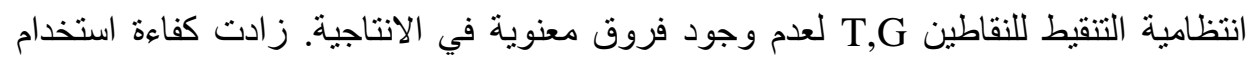

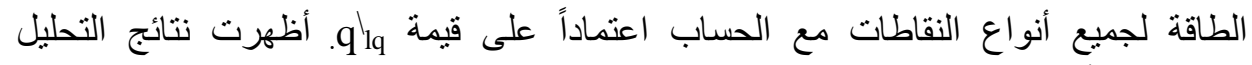

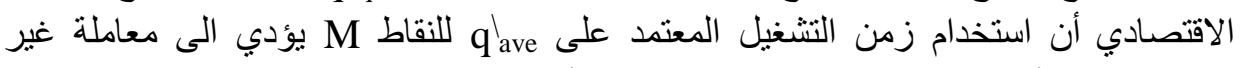

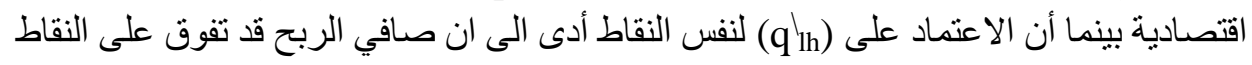

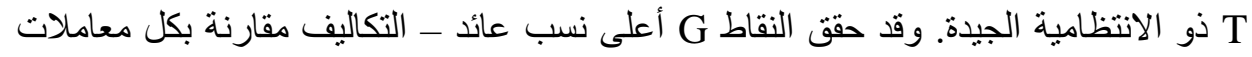

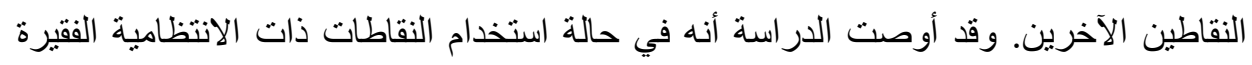

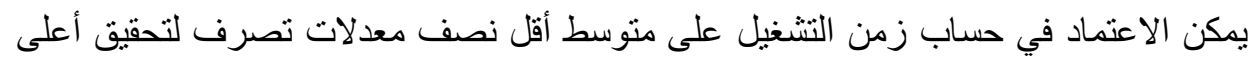

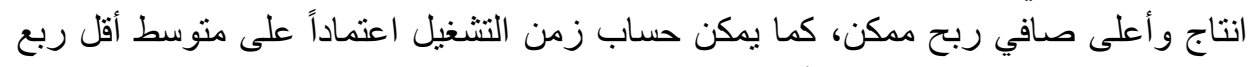
معدلات تصرف للحصول على أعلى كفاءة استخدام للطاقة في حال التكلفة العالية لمصادي اعنى

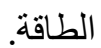

